\title{
Work Attitudes and Work Ethic as Predictors of Work Engagement among Polish Employees
}

\begin{abstract}
The purpose of this study was to investigate the relationship between work engagement and the psychological traits of employees, such as attitudes towards work and work ethic. Additionally, the study included demographic characteristics of employees and organizational characteristics. Research was conducted using the Polish adaptations of two well known methods: Multidimensional Work Ethic Profile and Utrecht Work Enagagement Scale, as well as the Work Attitude Questionnaire (WAQ) - a new Polish method. 360 adult employees of two large Polish regions took part in the study. The analysis showed a significant influence of hedonic-autotelic attitude, as well as four dimensions of work ethic on work engagement. It seems to be an important conclusion that work engagement turned out to be far more determined by the subject's psychological traits than demographic and organizational ones. These results, indicating the special role of the perception of work as a central value, can be used only in the area of attitudes towards work formed during adolescence (e.g., at school, in career counseling) but also in the area of motivating the employees by the organization.
\end{abstract}

Key words: work ethic, job attitudes, work engagement, centrality of work, work psychology, Poland

\section{Introduction}

At the time when the mere fact of having a job and adequate salaries are not the most important motivators for working in many cases, employers and researchers of motivation to work more often wondered how attitudes towards work could influence this motivation. According to a survey conducted by the European Social Survey (Sedlak\&Sedlak, 2012), among the seven major motivators for Europeans, "job retention" is in the second place, and "the desire to obtain rise or promotion," only in fifth place. In first place is the satisfaction with achievements. It appeared that in Poland similar results were obtained. What is interesting, the respondents reported, that "everyone should always try" is more important motivator than money and promotion.

Thus it appears that among the attitudes that could have enormous implications are probably work ethic and attitude to paid employment as such. Both attitudes relate to treating work as a valuable activity, but they seem to be qualitatively separable attitudes at the same time.

This article presents the results of a study on the relationship between work engagement (as a manifestation of motivation) and the attitudes towards work (hedonicautotelic, normative) and work ethic. Work attitudes and dimensions of work ethic are presented as job resources (personal resources) which are in a positive relation to work engagement ( $\mathrm{Li}$ et al., 2014).

\section{Attitudes towards work}

A significant subjective variable, which concerns motivation to undertake effort at work, is an attitude to work, understood as an attitude to specific work (e.g., in a concrete organization, or more generally as an attitude to work as such). By taking a look back at the evolution of work functions across centuries (Czerw, 2013), work was a life necessity in early human history, namely in tribal communities. Each adult and able person worked so that their family could survive and live safely. In ancient times, work was associated with humiliating physical activity and was mainly typical of slaves. Free people despised work and gave priority to intellectual development (which was not regarded as work) over a physical one. In the middle ages, another view on work dominated - such as treating

\footnotetext{
* University of Social Sciences and Humanities Faculty in Poznań, Department of Work and Organizational Psychology, gen. Tadeusza Kutrzeby 10, Poznań, Poland PL 61-719, agnieszka.czerw@swps.edu.pl

** University of Silesia in Katowice, Department of Work and Organizational Psychology, Grazynskiego 53, Katowice, Poland PL 40-126, damian.grabowski@us.edu.pl
} 
work as punishment for original sin and as a way to redeem sins. Thus, on the one hand, work was a moral duty and a source of virtue (it provided protection from addictions and idleness), whereas on the other hand, it was linked with exhaustion, painstaking effort, painful and depressing duty or even coercion. Radical changes in the perception of work appeared in the $17^{\text {th }}$ century although favorable ground had been prepared earlier by the Reformation. The reformers like Luther or Calvin had stressed a sacrificial character of work, already rooted in Christianity, whereas the post-Reformation intellectualists assumed wealth to be a sign of good work performance and therefore redemption (Miller et al., 2002). Liberalism emphasized the importance of enrichment and productivity. Furthermore, liberalism started to underline human needs and a possibility of their realization through the use of financial means. Consequently, work became the measure of an individual's value. Nonetheless, in the $19^{\text {th }}$ century, work was viewed again as unpleasant and burdensome. What epitomized the industry of the time was the depersonalization of workers and the scandalous conditions of work. This period also contributed to differentiating the working class. With time, however, the process of preparing a person for work, as well as realizing work itself became an opportunity for subject development. As a consequence, at the turn of the $21^{\text {st }}$ century, a great pressure to build an economy based on knowledge and values appeared which resulted in acknowledgement of issues like solidarity, cooperation, respect, mutual obligations (see a contemporary concept of psychological contract). In effect, an optimal use of human capital in the organization which guaranteed work satisfaction gained value.

It seems that the whole historic evolution of attitudes towards work can be reflected in today's view of work. It fulfills various functions which can represent different attitudes in the eyes of the employees (see Houston, 2011; Skarżyńska, 2002). They can be defined as a punitive attitude (i.e., perceiving work as an imposed way of behavior, whereas its performance may be linked with the feeling of unjust exploitation); instrumental or utilitarian, pragmatic attitude, characterized by the subject appreciating work because of material advantages and a possibility of fulfillment of their needs; finally autotelic, with work as a purpose in itself and a basis for personal development. Another close term for the attitudes described above is the meaning (importance) of work (Kanungo, 1982; Wrzesniewski, Dutton, \& Debebe, 2003). Furthermore, Amy Wrzesniewski underlines in her scholarship that work fulfils different functions and thus can be treated as a job, a career or a calling (Wrzesniewski, McCauley, Rozin and Schwartz, 1997). A job is understood as existentially necessity; a career as a promotion and climbing up the organizational hierarchy ladder, whereas a calling is a pleasant engagement at work. All these distinctions are by definition close to punitive and instrumental (a job) and autotelic functions (a career and a calling), but it appears they cannot be associated with them.

Apart from the three basic attitudes (instrumental, punitive and autotelic) as stated before, the perception of work in a normative way should be emphasized, where work is a duty, obligation for society, a specific payment of debts (e.g., for the opportunity of receiving education). Such an attitude was taken into account while constructing a Polish diagnostic method for attitudes towards work. Based on these four theoretical attitudes towards work, the Work Attitudes Questionnaire was created (Czerw, 2013). A factor analysis revealed, however, only two clearly defined dimensions: a hedonic-autotelic attitude and a normative one.

A hedonic-autotelic attitude consists in perceiving work function as progressive, but also a pleasant one. Such perception of work function may be contrasted with a punitive attitude. Hence, it could be said that this dimension is a particular continuum. At one extreme of this continuum we find taking pleasure in work (also stemming from self-fulfillment) and at the opposite extreme we find distress and negative attitude towards work. Thus, a high adherence to this dimension means work is perceived as an opportunity for personal development and the one that brings both psychological and emotional advantages. A low score, on the other hand, means that work has been seen as an unpleasant activity, performed due to economic necessity or coercion, and the one that entails costs and distress, rather than profits.

A normative attitude refers to the normative function of work, which so far has been absent in the literature. The normative function corresponds to the feelings of pride, obligation and respect towards work. A high score in this case is associated with the perception of work as an activity that defines identity and a subject's social role. A low score, however, indicates underestimating work in the social context and negating its role in building the value of an individual.

By analyzing both attitudes, they may be differentiated by locating potential advantages that result from work performance. Work may thus be perceived as a source of profits for a subject (hedonic-autotelic attitude) or as a way to offer advantages for others by performing work (normative attitude). It could also be compared with preference for a personal, egocentric or even individualistic (i.e., hedonic-autotelic) perspective or collectivist and communal (normative) perspective.

\section{Work ethic as a system of attitudes towards work}

The concept of work ethic also refers to the meaning of 'work in itself.' The definition of this construct comes from the works of German sociologist Max Weber (1958), and more precisely from the essay entitled "The Protestant Ethic and the Spirit of Capitalism," published between 1904 and 1905 and the article "The Protestant Sects and the Spirit of Capitalism," published in 1906. Weber describes therein an ideal type of the "spirit of capitalism" and the concept of "protestant ethic."

Visibly, work ethic refers both to the spirit of capitalism, just like the protestant work ethic, or rather the ethic of ascetic Protestantism, a doctrine that favors continuous and persistent professional occupation which assures the state of grace. Currently, work ethic, however, is 
associated with a process of valuing work outside religion. This ethic evaluates work both in a moral and normative sense. Work is good and virtuous in a moral sense, whereas it is a desirable, central element of life in a normative sense, but not necessarily in a moral sense (i.e., assuming good). Either way, work is a cognitive category in the system of knowledge that consists of the categories of "how it should be" (Grabowski, 2012).

From a psychological viewpoint, work ethic is primarily a system of attitudes and secondly a system of convictions (belief-system). Attitudes and convictions are similar concepts. Attitudes may be inferred as comprising convictions. While attitudes are assumed to contain cognitive, emotional, and behavioral components, convictions refer only to the first two (cognitive and emotional ones) and are often presented as an assessment and emotional element of attitudes themselves (Reykowski, 1998). These convictions emphasize importance, meaning and value of work, time and independence (Christopher et al., 2008). Miller et al. (2002) describe work ethic as a construct that consists of seven dimensions, including:

1. allocating value in hard work - belief in the virtue of hard (intensive) work, conviction that such work leads to reaching desired states of reality;

2. treating work as life's center - conviction for the great importance of work and perception of work as a central value in the life of an individual and society;

3. negative attitude of wasting time - conviction that time should be used effectively;

4. disapproval or unwillingness for free time - negative attitude to leisure and conviction for the low importance of human activities unrelated to work;

5. delay of gratification - orientation towards the future, patience in awaiting reward, cult of prudence;

6. self-reliance - praising independence in everyday work;

7. morality/ethic - belief in a just and moral existence in the Christian sense, readiness to behave honestly towards others.

Thus, work ethic appraises professional activity. Work appraisal may also be presented as a dimension; for example, Cherrington (1980) described the following steps of this dimension (see Figure 1):

- Workaholism, i.e., conventional point A that signifies work is treated as a central shifted value. Work acts like a drug - it is a way to reduce bad mood (i.e., fear, low self-esteem and disappointment).

- Work ethic, i.e., points B and C, treat work as an autotelic value (work is a value in itself and a moral duty - point B) and a generalized instrumental value (work is a value, since it serves society) - point $\mathrm{C}$.

- Worth ethic, i.e., points D and E. Treating work as a value only when it develops personality and selffulfillment (point D), also when work ensures a certain position and prestige (point E).

- $\quad$ Leisure ethic, i.e., points F and G. perception of work as an unfortunate duty which ensures a means for developing interests in free time, or as punishment or violence which paralyses the mind as point $\mathrm{G}$.

In this dimension, work ethic relates to normative and autotelic attitude, whereas worth ethic is related to fascinating and interesting work; point D relates to autotelic and hedonic attitudes and point E relates only to a hedonic one. Leisure ethic may be adjusted to an instrumental attitude. Nonetheless, point $\mathrm{G}$ is an element of a punitive attitude (see attitudes towards work described earlier in this article).

\section{Work Engagement}

However we understand the attitudes or convictions of work, they are undoubtedly a certain potential dimension of work motivation, i.e., a capability to act (affordance), which should, nonetheless, change into some kind of energy that would allow one to realize this motivation. An energyproviding component may be work engagement.

In the literature, there are two opposite, but closely linked, ways of understanding engagement in work. The first one places engagement in opposition to job burnout. For example, Maslach and Leiter's (2008) engagement is characterized by energy, involvement and efficacy. Yet, they are all direct opposites of the three dimensions of job burnout. The authors claim that in the case of job burnout, energy changes into exhaustion, involvement into cynicism, and efficacy into inefficacy. If this is the case, engagement could be understood as a symmetrical model. Namely, low scores in the three dimensions of the questionnaire of job burnout are synonyms for high engagement. Engagement may also be treated as a self-standing separate construct. In this sense, it is also negatively related to burnout, but

\section{Figure 1. Dimension of work's appreciation}

\begin{tabular}{|c|c|c|c|}
\hline \multirow{5}{*}{$\begin{array}{r}\text { Work is extremely } \\
\text { desirable }\end{array}$} & Workaholism & A & Central shifted value \\
\hline & \multirow{2}{*}{ Work ethic } & $\mathrm{B}$ & Autotelic value \\
\hline & & $\mathrm{C}$ & Generalized instrumental value \\
\hline & \multirow{2}{*}{ Worth Ethic } & $\mathrm{D}$ & Self-fulfillment \\
\hline & & $\mathrm{E}$ & Specific instrumental value \\
\hline \multirow{2}{*}{$\begin{array}{l}\text { Work is extremely } \\
\text { undesirable }\end{array}$} & \multirow{2}{*}{ Leisure Ethic } & $\mathrm{F}$ & Unfortunate duty \\
\hline & & G & Mind-numbing violence \\
\hline
\end{tabular}


it does not constitute an easy opposite. Engagement is thus defined as "... a positive, fulfilling, work-related state of mind that is characterized by vigor, dedication, and absorption" (Schaufeli, Salanova, Gonzalez-Roma, and Bakker, 2002, p. 74). Clearly, people involved in work are characterized by a high level of energy and psychological resistance at work, as well as readiness to invest effort in doing work and persistence even in the face of difficulties. Dedication is defined as experiencing the feeling of significance of work, or even pride in investing effort in work. Absorption is, on the other hand, characterized by full concentration and pleasant involvement with work, which resembles the notion of flow according to Michaly Csikszentmihalyi (1990), assumed to be a sign of internal motivation (Eccles \& Wigfield, 2002, p. 114). Kahn presents a completely different attitude in his works (1990). He links this notion with the fulfillment of a professional role. Work engagement appears when an organization member perceives their professional role as a possibility for physical, cognitive and emotional self-expression. That is why a key notion for engagement is identification with one's professional role. What differentiates both perspectives is reference to engagement in the professional role in the case of Kahn or to professional activities in the case of supporters of the opposing engagement and job burnout (Bakker, Schaufeli, Leiter, \& Taris, 2008). Nonetheless, independently of one's attitude, most researchers agree that engagement comprises the dimension of energy and identification with work.

Most importantly, there are also attempts to consider engagement as a subjective trait, state or even concrete behaviors. The authors of the article assume, following Schaufeli (Schaufeli, Bakker \& Salanova, 2006), that engagement is a kind of state to which a subject is introduced through means of certain conditionings. The reasons for work engagement may be located in two areas: a subjective one (specific features, personal resources) or an organizational one (e.g., work requirements). Among subjective reasons, for which the current research is concentrated, the most common ones may be proactivity, intrinsic motivation, positive affectivity, consciousness, extroversion, stability and emotional maturity, optimism (see Bakker et al., 2008). Clearly, the perspective of subject traits dominates. A quite interesting experience might be adding attitudes of subject traits to the determinants of engagement.

The most often used method for measuring engagement is the Utrecht Work Engagement Scale (UWES; Schaufeli, Bakker, \& Salanova, 2006) which consists of three dimensions: vigor, dedication and absorption. This method has been adopted in many countries and in most of them a three-factor structure has been confirmed (Bakker et al., 2008). There are also recorded examples of research where such a structure failed to be confirmed, including the Polish adaptation (Szabowska-Walaszczyk, Zawadzka, \& Wojtaś, 2011). However, the authors of the original scale claim the general results of work engagement may sometimes be even more useful than the results of three separate dimensions which is why this tool in the Polish version is also worth recommending.

\section{The J-DR model - a theoretical starting point for proposed research}

In studies of work engagement, has been broadly used the JD-R model (Bakker et al., 2007; Li et al., 2014). Within the JD-R model, there appear two processes, job demands (JD) and job resources (JR), which influence job burnout and work engagement. JD refer to the physical, social, psychological - such as cognitive or emotional - or organizational aspects of the job that determine continuous physical or mental effort (Demerouti et al., 2001). JD include work overload, role stress, role conflict, time pressure, emotional demands, and work-family conflict ( $\mathrm{Li}$ et al., 2014).

JR refer to the physical, social, psychological, or organizational aspects of the job that may be helpful for individuals to be successful at work, decrease the level of JD and the related physiological and psychological costs, and encourage individual development and progress (Hakanen et al., 2006). JR contain job autonomy, job security, social support, performance feedback, organizational justice, and organizational climate (Bakker \& Demerouti, 2007; Demerouti et al., 2001).

According to the JD-R model, JD negatively predict work engagement, and JR are in a positive relation to work engagement (Bakker \& Demerouti, 2007; Demerouti et al., 2001). Additionally, high JD result in a tighter link between JR and work engagement. The JD-R model has been broadly used in studies of work engagement, by using definite subsets of JD and JR as the antecedent and outcome variables (e.g. work engagement) (Bakker et al., 2007; Li et al., 2014).

Very important is the fact that the authors extend recently the model including in it an employee's personal resources. They suggest the importance of such personal traits as for example positive self-evaluations, predict goal setting, motivation, performance, job and life satisfaction, and other desirable outcomes (Bakker, Demerouti, \& Sanz-Vergel, 2014). Therefore, taking this into account, in this article, it is assumed that attitudes towards work (hedonic-autotelic attitude, normative attitude), including work ethic may be treated as personal resources, i.e. psychological - such as cognitive or emotional aspects of the job that are in a positive relation to work engagement. These attitudes and work ethic may be treated as predictors of work engagement (cf. Brown, 1996). However, these are only assumptions as there is not enough research showing relations of attitudes and work ethic with work engagement. These assumptions can be based on the research on a construct similar to work engagement, i.e. job involvement. For example Saal (1978) presented work ethic as a predictor of job involvement. Similarly, Brown (1996), showed the classification of antecedents, correlates, and consequences of job involvement. In this classification, job resources, i.e. autonomy and feedback are antecedents of job involvement. Also work ethic is presented by this author as antecedent of job involvement. Job involvement correlates positively with work engagement (Hallberg, Schaufeli, 2006). 


\section{The purpose of the research}

The literature in the field of work psychology that focuses on the problem of work engagement concerns mostly the organizational context or subject-employee traits.

On the other hand, when it comes to work attitudes, those not linked with one's own organization, but with work as such, barely exist in Polish and the world literature. Hence, the study presented in this article aimed at examining whether attitudes associated with professional occupation as such, not in a concrete organization, are linked with readiness to engage in work. The authors treat this research as exploration of a little known area (cf. Brown, 1996; Paullay et al., 1994). For this reason, before proceeding to the research, one hypothesis and two questions were presented.

- Hypothesis 1: Attitudes toward work, work ethic dimensions and work engagement are mutually related, but two attitudes (normative and hedonicautotelic) toward work and seven dimensions of work ethic and work engagement are ten distinct constructs.

- Question 1: Can work attitudes and work ethic dimensions be treated as predictors (i.e. job resources) of work engagement? In other words, Can work attitudes and work ethic dimensions be treated as job resources in the JD-R model?

- Question 2: Which dimensions of work attitude and work ethic are the most strongly related to work engagement?

- Question 3: Are demographic and organizational variables predictors of work engagement?

\section{Method}

\section{Measures}

To measure the independent variables (predictors), we used the attitude towards work questionnaire, a tool for work ethic measurement. For the dependent variable, we used the work engagement questionnaire.

Work Attitudes Questionnaire (WAQ) consists of 32 positions that comprise two scales (Czerw, 2013). The first of them is hedonic-autotelic attitude (HAA) $(\alpha=0.852)$. In this case, a high score means work is perceived rather in the context of social than individual benefits, as an activity that defines identity and the subject>s social role. A low level signifies underestimating work in the social context and negating its role in building up human values.

The other scale is normative attitude (NA) $(\alpha=0.852)$. A high score in this case means perceiving work in terms of social rather than individual benefits, as well as an activity that defines both the subject's identity and social role A low score implies work is underestimated in the social context and its role in building human values is negated. By filling in the PWP questionnaire, the subjects express their attitude to each position on a 5-point consensus-based scale.

The Polish adaptation of the Multidimensional Work Ethic Profile (MWEP) (Miller et al., 2002), was elaborated by Chudzicka-Czupała and Grabowski
(Chudzicka-Czupała, Cozma, Grabowski, \& Woehr, 2012). In this research, a shortened version of the questionnaire was applied. Each of the seven scales was shortened to five items. The criteria for keeping the remaining items were as follows: the item discrimination indices (itemtotal correlation), their factor loadings and contents. In consequence, the shortened version of the scale consists of 35 items and seven scales.

- hard work $(H W)$ - belief in the virtue of hard work, conviction that such work leads to success $(\alpha=0.835)$; centrality of work $(\mathrm{CW})$ - treating work as a central value in life whose performance provides satisfaction and fulfillment ( $\alpha=0.797)$;

negative attitude to wasting time $(W T)$ - conviction about the value of effective use of time $(\alpha=0.691)$;

anti-leisure attitude (anti-LEI) - lack of acceptance towards free time activities $(\alpha=0.812)$;

delay of gratification $(D G)$ - conviction about the value of prizes located in the future $(\alpha=0.792)$;

self-reliance (SREL) - conviction that one has to count on oneself $(\alpha=0.828)$;

morality/ethics $(M E)$ - readiness to act honestly towards others $(\alpha=0.600)$.

To measure the intensity of each of the seven dimensions of work ethic, a set of five-point Likert scales was applied ranging from $1=$ "I strongly disagree" to $2=$ "I strongly agree." A sum of all the items constitutes the so called MWEP global indicator (GI).

Utrecht Work Engagement Scale (UWES-PL) is a Polish adaption (Szabowska-Walaszczyk et al., 2011) of the method created by Schaufeli et al. (2006). In the Polish version, the questionnaire is one dimensional. The measurement was made on a 7-point frequency scale ranging from 0 (never) to 6 (always).

The standardized questionnaire form in the research comprised demographic and organizational traits including gender, age, education, seniority (period of employment), number of workplaces and types of occupations throughout one's professional career, professional status, position, size of companies (micro, small, average-sized, big companies) and the range of their activities (international, national).

\section{Participants}

The group of subjects consisted of 360 adult workers (however, in some analyses a slightly smaller number was considered due to a lack of data for some variables), representing various professions. The research comprised two Polish regions: Lower Silesia (217 subjects) and Upper Silesia (143 subjects).

The subjects were people employed in organizations of various sectors. There were 205 women and 155 men. The average age was $39.24(\mathrm{SD}=12.55)$, average employee seniority was $16.54(\mathrm{SD}=12.62)$. The subjects had mostly secondary (43.6\%) and higher education (39.7\%); the remaining subjects had vocational $(9.4 \%)$, undergraduate $(6.1 \%)$ and primary education $(1.1 \%)$. The sample was balanced when it comes to the size of companies in which the subjects were employed. Namely, 24.4\% persons worked for micro companies, $29.4 \%$ persons worked 
for small business companies, $24.75 \%$ for average-sized ones, and $21.1 \%$ for big companies. They were generally domestic companies $(71.9 \%)$, but some international ones $(28.1 \%)$. Most subjects had permanent contracts $(73.9 \%)$, the remaining were self-employed $(13.1 \%)$ or had order contracts $(13 \%)$. The subjects held positions of specialists $(26.4 \%)$, managers $(19.4 \%)$, non-management office workers $(17.8 \%)$ and others $(26.9 \%)$. The subjects were quite active in the job market because most of them changed work two to three times in the course of their career $(\mathrm{M}=3.38 ; \mathrm{SD}=2.02)$ and they performed two types of jobs twice a kind of job performed $(\mathrm{M}=1.94 ; \mathrm{SD}=1.51)$.

\section{Results}

The first step in the analytical procedure was checking the relationship between the independent variables and the dependent one. Table 1 presents the analysis of Pearson correlations for the attitudes towards work and work ethic with work engagement. Clearly, if relationships appear, they are always positive. The MWEP global indicator correlates on an average level with (almost 0.5) UWES-PL. The relationship between engagement (UWES) and attitudes towards work is stronger (more than 0.5) in the case of HAA and weaker in the case of NA. The strongest relationship between engagement and the work ethic questionnaire appeared for the $\mathrm{CW}$ dimension (above 0.5 ). The remaining relationships are significant but not strong and two scales, DG and SREL, are not related with work engagement. HAA and NA are significantly related to work ethic dimensions. We can also observe strong correlations (above 0.5 ) between: 1. HAA and CW, 2. HAA and antiLEI as well as 3. NA and HW.

The higher correlations between the constructs WAQ, MWEP and UWES ranged between .394 and .616, indicating between $16 \%$ and $31 \%$ of shared variance (see Table 1). This supports the assumption that the constructs are related but do not overlap to the extent where redundancy was actualized. The results of Confirmatory Factor Analysis (CFA) (Table 2) corroborated this assumption, indicating that the model specifying seven dimension of work ethic, two attitudes to work (HAA and NA) and work engagement as ten distinct constructs showed a superior fit to data as compared to the onedimensional model.

It could be successfully established that seven components of work ethic (MWEP), two attitudes to work (WAQ) and work engagement (UWES) represent ten empirically distinct constructs. Thus, work ethic dimensions and work attitudes can be treated as predictors of work engagement. For that reason, CFA provides support for discriminant validity of Polish short version of MWEP.

Besides, one dimensional ANOVA and Post Hoc LSD Tests (see Table 3) indicate that people who show higher work engagement are those:

1. with higher education,

2. self-employed,

3. in a management position or position of specialists,

4. employed in companies operating internationally.

To investigate a more detailed relationship between particular variables and check the direction of dependencies, the analysis of multiple hierarchical regression was also applied. A model was constructed in which attitudes towards work and work ethic dimensions were treated as explanatory variables, whereas engagement was treated as an explained variable. Two blocks of variables were introduced. The first one was demographic and organizational variables such as gender, age, education, seniority, position, range of company operations (domestic, international), number of workplaces

Table 1. Relationships between work engagement (UWES-PL) and work attitudes (WAQ) and work ethic (MWEP) - correlations and inter-correlations (WAQ and MWEP) (N=356)

\begin{tabular}{|c|c|c|c|c|c|c|c|c|c|c|}
\hline & $\begin{array}{l}\text { WAQ- } \\
\text { HAA }\end{array}$ & $\begin{array}{c}\text { WAQ- } \\
\text { NA }\end{array}$ & $\begin{array}{c}\text { MWEP- } \\
\text { HW }\end{array}$ & $\begin{array}{c}\text { MWEP- } \\
\text { CW }\end{array}$ & $\begin{array}{c}\text { MWEP- } \\
\text { WT }\end{array}$ & $\begin{array}{l}\text { MWEP- } \\
\text { Anti-LEI }\end{array}$ & $\begin{array}{c}\text { MWEP- } \\
\text { DG }\end{array}$ & $\begin{array}{l}\text { MWEP- } \\
\text { SREL }\end{array}$ & $\begin{array}{c}\text { MWEP- } \\
\text { ME }\end{array}$ & $\begin{array}{c}\text { MWEP } \\
\text { (GI) }\end{array}$ \\
\hline & 1. & 2. & 3. & 4. & 5. & 6. & 7. & 8. & 9. & 10. \\
\hline 2. & 0.551 & & & & & & & & & \\
\hline 3. & 0.328 & 0.417 & & & & & & & & \\
\hline 4. & 0.616 & 0.394 & 0.423 & & & & & & & \\
\hline 5. & 0.273 & 0.307 & 0.309 & 0.403 & & & & & & \\
\hline 6. & 0.450 & 0.269 & 0.175 & 0.479 & 0.130 & & & & & \\
\hline 7. & 0.200 & 0.312 & 0.515 & 0.299 & 0.355 & 0.125 & & & & \\
\hline 8. & -0.008 & 0.047 & 0.168 & 0.004 & 0.050 & -0.235 & 0.091 & & & \\
\hline 9. & 0.168 & 0.115 & 0.111 & 0.095 & 0.194 & 0.013 & 0.078 & 0.149 & & \\
\hline 10. & 0.537 & 0.494 & 0.727 & 0.725 & 0.615 & 0.476 & 0.667 & 0.282 & 0.341 & \\
\hline UWES-PL: & 0.529 & 0.292 & 0.283 & 0.579 & 0.318 & 0.330 & 0.089 & 0.092 & 0.147 & 0.479 \\
\hline
\end{tabular}

Note: Correlations greater than 0.11 are significant at $\mathrm{p}<0.05$, and those greater than 0.17 are significant at $\mathrm{p}<0.01$, two-tailed. 
Work attitudes, ethic and engagement

Table 2. Confirmatory Factor Analyses of Measurement Models for UWES-PL, MWEP and UWES-PL (N=357)

\begin{tabular}{lcccccccc}
\hline \multicolumn{1}{c}{ Model } & $\chi^{2}$ & $d f$ & $\chi^{2} / d f$ & RMSEA & CFI & NFI & SRMR & $\Delta \chi^{2}$ \\
\hline One-factor $^{\mathrm{A}}$ & $19698.74^{*}$ & 3402 & 5.79 & 0.120 & 0.86 & 0.81 & 0.100 & $12835.60^{*}$ \\
\hline Three-factors $^{\mathrm{B}}$ & $12475.81^{*}$ & 3399 & 3.67 & 0.087 & 0.89 & 0.84 & 0.089 & $5612.70^{*}$ \\
\hline Four-factors $^{\mathrm{C}}$ & $11385.37^{*}$ & 3396 & 3.35 & 0.081 & 0.90 & 0.85 & 0.088 & $4522.26^{*}$ \\
\hline Ten-factors $^{\mathrm{D}}$ & $6863.11^{*}$ & 3357 & 2.04 & 0.054 & 0.94 & 0.89 & 0.073 & \\
\hline
\end{tabular}

* Chi-square change significant at $p<.001$; all chi-square values are significant at $p<.01$.

A - all items combined. The one-factor "Work attachment" model constrains UWES-PL, MWEP, WAQ and to a single latent variable.

B - The three-factor model is the hypothesized model of three latent variables, i.e. hedonic-autotelic attitude (WAQ - HAA), normative attitudes (WAQ - NA and MWEP) and work engagement (UWES).

C - The four-factors model is the hypothesized model of four latent variables: WAQ, MWEP and UWES.

D - The ten-factors model is the hypothesized model of ten latent variables: HAA, NA, HW, CW, WT, anti-LEI, DG, SREL, ME and UWES.

and types of work in the professional career, as well as company size. The second block was WAQ questionnaire subscales and WPEP scales. The results of these analyses are presented in Table 4.

The table above reveals that demographic and organizational variables explain around $10 \%$ of the variance of work engagement. By adding psychological variables to the model, this value rose to around $44 \%$. The change in $\mathrm{R}$ square was 0.34 . For this reason, model 2 was considered the one that better explained the conditions of work engagement and this model provided the grounds for the authors to draw the conclusions presented later. Please note that in comparison to model 1, the range of company activities lost their significance and education did not impact as strongly. Still, with better education chances, work engagement increases, whereas among psychological variables the HAA, CW, WT and SREL, as well as a lower tendency to postpone gratification (DG) significantly enhanced work engagement

As was true in our data, predictors are intercorrelated (see Table 1). It is associated with the problem of identification of the correct predictors. To deal with the problem of intercorrelated predictors, dominance analysis provides an average variability accounted for by a given predictor by examining different sets of regression analyses. To the extent a given predictor consistently accounts for more variability in predicting work engagement across the set of multiple regressions, that predictor is said to

Table 3. Relationships between work engagement (UWES-PL) and demographic and organizational variables. Results of ANOVA and Post Hoc LSD Tests $(\mathrm{N}=356)$

\begin{tabular}{|c|c|c|c|c|c|c|c|}
\hline Education & higher & undergraduate & secondary & vocational & elementary & $\mathrm{F}$ & $\mathrm{p}$ \\
\hline M & $68.57^{\mathrm{A}}$ & $60.09^{\mathrm{B}}$ & $58.23^{\mathrm{B}}$ & $60.65^{\mathrm{B}}$ & $59.50^{\mathrm{B}}$ & 8,05 & 0.001 \\
\hline SD & 14.35 & 15.84 & 16.57 & 19.25 & 24.57 & & \\
\hline Status: & self-employed & $\begin{array}{c}\text { contract } \\
\text { (full time job) }\end{array}$ & order contract & & & & \\
\hline M & $67.96^{\mathrm{A}}$ & $62,49^{\mathrm{B}}$ & $58.47^{\mathrm{B}}$ & & & 3.78 & 0.05 \\
\hline SD & 15.83 & 16.26 & 18.79 & & & & \\
\hline Position: & managers & office workers & specialists & $\begin{array}{l}\text { production } \\
\text { workers }\end{array}$ & & & \\
\hline M & $70.22^{\mathrm{A}}$ & $58.84^{\mathrm{B}}$ & $65.99^{\mathrm{A}}$ & $55.65^{\mathrm{B}}$ & & 8.52 & 0.001 \\
\hline SD & 17.06 & 15.71 & 14.12 & 17.00 & & & \\
\hline $\begin{array}{c}\text { Range of company } \\
\text { activities: }\end{array}$ & national & international & & & & & \\
\hline $\mathrm{M}$ & $61.59^{\mathrm{A}}$ & $65.47^{\mathrm{B}}$ & & & & 3.92 & 0.05 \\
\hline SD & 16.85 & 16.51 & & & & & \\
\hline
\end{tabular}

Note: Means within the same row with different superscripts are significantly different (LSD tests; $\mathrm{p}<.05)$; $\mathrm{p}$ : significance. 
Table 4. Hierarchical multiple regression with demographic and organizational variables (DOV), work attitudes (WAQ), work ethic (MWEP) predicting work engagement (UWES-PL) (N=356)

\begin{tabular}{|c|c|c|c|c|c|c|}
\hline Dependent variable & Block number, independent variable $\left(\beta^{*}\right)$ & $\mathbf{R}$ & $\mathbf{R}^{2}$ & $\Delta \mathbf{R}^{2}$ & $\mathbf{P}$ & $\mathbf{S R}^{2}$ \\
\hline \multirow[b]{4}{*}{$\begin{array}{l}\text { Work engagement } \\
\text { (UWES-PL) }\end{array}$} & Model 1: $F(10)=4.90 ; p<0.001$ & 0.35 & 0.13 & 0.13 & 0.001 & 0.10 \\
\hline & $\begin{array}{l}\text { 1. }(\mathrm{DOV}) \text { : } \\
\text { Education }(\beta=0.25) \\
\text { Range of company activities }(\beta=0.11)\end{array}$ & & & & & \\
\hline & Model 2: $F(19)=15.47 ; p<0.001$ & 0.68 & 0.47 & 0.34 & 0.001 & 0.44 \\
\hline & $\begin{array}{l}\text { 1. DOV: } \\
\text { Education }(\beta=0.13) \\
\text { 2. Psychological variables: } \\
\text { HAA }(\beta=0.26) \\
\text { CW }(\beta=0.35) \\
\text { WT }(\beta=0.11) \\
\text { DG }(\beta=-0.13) \\
\text { SREL }(\beta=0.11)\end{array}$ & & & & & \\
\hline
\end{tabular}

* only significant beta indicators are shown

SR2 - adjusted R2

DOV - demographic and organizational variables

dominate the other predictors in the multiple regression analyses (see Budescu, 1993; Christopher et al., 2008).

To carry out dominance analyses for work engagement, first we examined the amount of variability accounted for by each predictor with no other predictors in the regression equation. Next, we studied the amount of variability accounted for by each predictor after all eight other predictors were entered earlier. Finally, we calculated the mean of the two amounts of variability accounted for by each predictor to illustrate its relative importance.

Table 5 contains the results of dominance analysis. CW and HAA dominated all other predictors across both sets of regressions. However, the least important predictors are SREL and ME.

\section{Discussion}

Summing up, the hypothesis for a positive relationship between attitudes towards work and work ethic with work engagement seems to have been largely confirmed (cf. Brown, 1996). Although not all of the assumed psychological variables turned out to be significant in the regression model (despite significant relationships on the level of correlation analysis), the research results showed an unequivocal strong relationship between work engagement, a hedonic-autotelic attitude and work ethic dimension (i.e., perception of work as a central value).

Among the weaker predictors of work engagement we can distinguish: negative attitude to wasting time,

Table 5. Results of dominance analysis on work engagement (UWES-PL) (N=356)

\begin{tabular}{cccc}
\hline Independent variables & $R^{2}$ Alone & Additional $R^{2}$ after other predictors entered & Mean $R^{2}$ \\
\hline HAA & 0,280 & 0,003 & 0,142 \\
\hline NA & 0,090 & 0,001 & 0,046 \\
\hline HW & 0,080 & 0,003 & 0,042 \\
\hline CW & 0,334 & 0,061 & 0,198 \\
\hline WT & 0,102 & 0,012 & 0,057 \\
\hline Anti-LEI & 0,109 & 0,002 & 0,056 \\
\hline DG & 0,008 & 0,018 & 0,013 \\
\hline SREL & 0,008 & 0,009 & 0,009 \\
\hline ME & 0,022 & 0,001 & 0,012
\end{tabular}


anti-leisure attitude, normative attitude and belief in the virtue of hard work. Importantly, the scale of postponing gratification was kept against our expectations, which in the regression analysis turned out to be a negative (not positive) as well as a weak engagement predictor (correlation analysis showed that delay of gratification was very weakly related to work engagement). Delay of gratification,selfreliance and readiness to act honestly towards others turned out to be very weak predictors of work engagement.

By analyzing the affectivity of the independent variables on the dependent one, the strongest predictors of work engagement turned out to be perception of work as a central value in life, perceived also as an aim in itself and a hedonic-autotelic attitude. Therefore, perception of work turned out to be an opportunity for development. Also, self fulfillment through work performance, combined with treating work as a central (autotelic) value, was a high engagement indicator. It shows that employees motivated by internalized attitudes and a specific way of thinking about work employ a lot of vigor, dedication and absorption which corresponds with the definition of engagement. Vigor is understood here as a high level of energy and psychological resistance during work performance, and what follows, readiness to invest one's own effort in work performance as well as endurance in action. Dedication concerns experiencing the feeling of work significance, or even pride from work. On the other hand, absorption is characterized by full concentration and pleasant immersion in work. Evidently, results for independent variables obtained in our research correspond with a profile of an employee engaged with work and the one who experiences work satisfaction. After all, numerous studies suggest a strong relation between engagement and work satisfaction (see Alarcon \& Lyons, 2011).

It may be the case that pleasant feelings associated with work are in a sense the key issue. By assuming that generally performing pleasant work may be considered as gratifying, it is not surprising that people with a weak inclination to postpone gratification, stronger inclination to save time, focused and self-relying tend to work faster, treat work as a reward, and present higher work engagement.

Based on the research results presented in this article, the following profile describes a person engaged at work: an employee with a degree, self-employed, in a management position or specialist, and employed by an international company. Nevertheless, this employee treats, above all, their occupation as a central, particularly important aspect of their life and is convinced that work may bring joy and self-fulfillment. Besides, such a person does not tolerate wasting time, so they concentrate on fulfilling their tasks, also assuming that they should rely on themselves rather than others. Additionally, it is a person who does not like postponed gratification, in other words, a person that aims at gaining a quick reward, like the pleasure derived from work. It seems that a reward may not only be a further aim (telic motivation), such as performing the task, but a permanent pleasure in doing the task itself (paratelic motivation) remains equally important. Thus, such a profile must match a person oriented towards intrinsic motivation (which was the starting point for this study) who undertakes challenges and probably aims at mastery. Nonetheless, a trace of competition cannot be excluded either, which may be associated with certain intensification of the orientation towards achievements. The motivation of such a worker, if it does not equate, at least stays close to intrinsic motivation according to Ryan and Deci (2000).

In summary, noticeably work engagement turned out to be far more determined by the subject's psychological traits than demographic and organizational ones. Additionally, these traits, as specific attitudes, probably stem from early periods of human life.

The process of upbringing in the family home and at school, thus plays a considerable role. It seems that the impact of views on work represented by parents and other important adults on a child's or teenager's environment may unintentionally model his or her general attitude towards work. These attitudes can also be shaped more actively through planned activities under professional guidance. Vocational counseling typically focuses on providing young people with knowledge about occupations and the labor market and on discovering individual predisposition to a particular type of profession (it is so in Poland). Thanks to this practice a young man is provided with a general positive attitude towards work as a central value in human life.

As it is widely known, attitudes formed in youth are not easily changed in adult life. This being so, it is worth considering if, from the perspective of an organization, it does not look somewhat fatalistic. In other words, if a desirable model of an employee is not found, it will be difficult to count on strong work engagement. In fact, this assumption is utterly wrong, taking into account the following few statements.

Firstly, psychology stresses the enormous power of a subject's motivation for change provided, for some important reasons, that this change is necessary and useful for the subject. Although attitudes are fairly stable, they are not invariable. It means that situational factors strong enough to modify these attitudes may be at the hands of the organization that employs the subject. As an example, they may serve to raise the level of employees' autonomy by managers.

Secondly for objective reasons, this study has been limited when it comes to organizational variables. Perhaps in the future, this research problem should comprise more concrete traits of the organization. However, to perform the research in this way, concentration on a concrete organization would be necessary. The employees' psychological traits could then be examined for their significance controlling for such organizational variables such as the values realized by the organizational culture, motivational system or employee evaluation. Undoubtedly, the research discussed in this article is merely a step towards discovering conditionings of work engagement and development of this idea seems extremely interesting from the position of both a researcher and organization. 


\section{References}

Alarcon, G.M., \& Lyons, J.B. (2011). The relationship of engagement and job satisfaction in working samples. Journal of Psychology, 145(5), $463-480$.

Bakker, A.B., \& Demerouti, E. (2007). The Job Demands-Resources model: State of the art. Journal of Managerial Psychology, 22, 309-328.

Bakker, A.B., Demerouti, E., \& Sanz-Vergel, A.I. (2014). Burnout and work engagement: The JD-R approach. Annual Review of Organizational Psychology and Organizational Behavior, 1, 389-411.

Bakker, A.B., Hakanen, J.J., Demerouti, E., \& Xanthopoulou, D. (2007). Job resources boost work engagement, particularly when job demands are high. Journal of Educational Psychology, 99, 274-284. http://doi.org/ftmrzh

Bakker, A.B., Schaufeli, W.B., Leiter, M.P., \& Taris, T.W. (2008). Work engagement: An emerging concept in occupational health psychology. Work \& Stress, 3, 187-200.

Brown, S.P. (1996). A Meta-Analysis and Review of Organizational Research on Job Involvement. Psychological Bulletin, 120, 235-255.

Budescu, D.V. (1993). Dominance analysis: A new approach to the problem of relative importance of predictors in multiple regression. Psychological Bulletin, 114, 542-551.

Cherrington, D. (1980). The work ethic. Working values and values that work. New York: Amacom, A division of American Management Associations.

Christopher, A.N., Zabel, K.L., Jones, J.R. (2008). Conscientiousness and work ethic ideology: A facet-level analysis. Journal of Individual Differences, 29, 189-198

Chudzicka-Czupała A., Cozma I., Grabowski D., \& Woehr D.J. (2012). A comparison of the Multidimensional Work Ethic Profile across two countries. Journal of Management and Business, 3(1), 14-33.

Csikszentmihalyi, M. (1990). Flow: The psychology of optimal experience. New York: Harper and Row.

Czerw, A. (2013). Co ludzie myślą o pracy zawodowej? Konstrukcja metody diagnozującej postawy wobec pracy [What do people think about work? The construction of attitudes to work diagnosing method]. Psychologia Spoleczna, 8(2), 219-233.

Demerouti, E., Bakker, A.B., Nachreiner, F., \& Schaufeli, W.B. (2001). The job demands-resources model of burnout. Journal of Applied Psychology, 86, 499-512.

Eccles, J., \& Wigfield, A. (2002). Motivational beliefs, values and goals. Annual Review of Psychology, 53, 109-132.

Furnham, A. (1990). The Protestant work ethic. The psychology of workrelated beliefs and behaviours. London: Routledge.

Grabowski, D. (2012). Etyka pracy jako zmienna psychologiczna [Work ethic as psychological variable]. Czasopismo psychologiczne, 18, 237-246.

Hakanen, J.J., Bakker, A.B., \& Schaufeli, W.B. (2006). Burnout and work engagement among teachers. Journal of School Psychology, 43, 495-513.

Hallberg, U., \& Schaufeli, W. (2006). "Same Same" But Different? Can Work Engagement Be Discriminated from Job Involvement and Organizational Commitment? European Psychologist. 11, 119-127.
Houston, D.J. (2011). Implications of occupational locus and focus for public service motivation: Attitudes toward work motives across nations. Public Administration Review, 71(5), 761-771.

Kahn, W.A. (1990). Psychological conditions of personal engagement and disengagement at work. Academy of Management Journal, 33, 692-724.

Kanungo, R.N. (1982). Measurement of job and work involvement. Journal of Applied Psychology, 67, 341-349.

Li, L., Zhong, J., Chen, Y., Xie, Y., Mao, S. (2014). Moderating effects of proactive personality on factors influencing work engagement based on the job demands-resources model. Social Behavior and Personality: an international journal, 42, 7-16.

Maslach, C., \& Leiter, M.P. (2008). Early predictors of job burnout and engagement. Journal of Applied Psychology, 93, 498-512.

Miller, J., Woehr, D., \& Hudspeth, N. (2002). The meaning and measurement of work ethic: Construction and initial validation of a multidimensional inventory. Journal of Vocational Behavior, 60, 451-489.

Paullay, I.M., Alliger, G.M. and Stone-Romero, E.F. (1994). Construct Validation of Two Instruments Designed to Measure Job Involvement and Work Centrality. Journal of Applied Psychology, 79, 224-228.

Reykowski, J. (1998), Belief Systems and collective action: changes in Poland from the psychological perspective. An applied psychology: an international review, 47, 89-108.

Ryan, R., Deci, E. (2000). Intrinsic and extrinsic motivations: classic definitions and new directions. Contemporary Educational Psychology, $25,54-67$.

Saal, F. E. (1978). Job involvement: A multivariate approach. Journal of Applied Psychology, 63, 53-61.

Sedlak\&Sedlak (2012). Raport „Co nas motywuje do pracy?” [Report „What motivates us for working?"]. http://www.rynekpracy.pl/ artykul.php/typ.1/kategoria_glowna.37/wpis.528 (access date: 03.05.2015)

Schaufeli, W.B., Bakker, A.B., \& Salanova, M. (2006). The measuremen of work engagement with a short questionnaire: A cross-national study. Educational and Psychological Measurement, 66, 701-716.

Schaufeli, W.B., Salanova, M., Gonzalez-Roma, V., \& Bakker, A.B. (2002). The measurement of engagement and burnout: A two sample confirmatory factor analytic approach. Journal of Happiness Studies, 3, 71-92.

Skarżyńska, K. (2002). Work as a cultural and personal value: Attitudes towards work in polish society. International Journal of Occupational Safety and Ergonomics, 8, 195-208.

Szabowska-Walaszczyk, A., Zawadzka, A.M., \& Wojtaś, M. (2011) Zaangażowanie w pracę i jego korelaty: adaptacja skali UWES autorstwa Schaufeliego i Bakkera [Engagement in work and its correlates: Schaufeli and Bakker UWES scale adaptation]. Psychologia Jakości Życia, 10, 57-74.

Weber, M. (1958). The protestant ethic and the spirit of capitalism. New York: Charles Scribner's Sons.

Wrzesniewski, A., McCauley, C., Rozin, P., Schwartz, B. (1997). Jobs, Careers, and Callings: People's Relations to Their Work. Journal of Research In Personality, 31, 21-33.

Wrzesniewski, A., Dutton, J.E., Debebe, G. (2003). Interpersonal sense making and the meaning of work. Research in Organizational Behavior, 25, 93-135. 